UDC 614.841

\title{
Experimental study of heat-insulating aerogel-based nanomaterials
}

\section{Authors:}

Igor R. Baikov,

Professor, Ufa State Petroleum Technological University; Russia, Bashkortostan Republic, pte.ugntu@rusoil.net

\section{Olga V. Smorodova,}

Associate Professor, Ufa State Petroleum Technological University; Russia, Bashkortostan Republic, Ufa, olga_smorodova@mail.ru

\section{Andrey Yu. Trofimov,}

Associate Professor, Ufa State Petroleum Technological University; Russia, Bashkortostan Republic, Ufa, trofimov_pte@mail.ru

\section{Elena V. Kuznetcova,}

Associate Professor, Ufa State Petroleum Technological University; Russia, Bashkortostan Republic, Ufa, nsp-rb@mail.ru

Abstract: Research and synthesis of materials with fundamentally new properties play the key role in the development of modern science and technology. The most perspective materials are considered to be aerogels: nanostructured materials with many useful properties. The mesoporous structure of airgels determines their widespread use, both in industry and in science.

Over the past few decades, nanostructured silica-based material has become an integral part of many industry segments: thermal and noise insulation, electronics, chemistry, medicine, environmental protection, industrial and fire safety, energy, aerospace industry, consumer goods and military technology.

The article discusses an experimental study of the heat-shielding properties of a heat-insulating material based on silicon oxide airgel - Insuflex. This is a flexible rolled material used for thermal insulation of elements of technological installations, pipelines, valves and control valves. Using the method of ordinal statistics, the exponential dependence of the coefficient of thermal conductivity of the airgel on the average temperature of the sample is determined. The results obtained indicate the possibility of energy-efficient use of the material in heat supply and heat consumption systems.

Keywords: thermal conductivity, thermal insulation, aerogel, modeling, measurement.

For citation: Baikov I.R., Smorodova O.V., Trofimov A.Yu., Kuznetcova E.V. Experimental study of heat-insulating aerogelbased nanomaterials. Nanotehnologii v stroitel'stve = Nanotechnologies in Construction. 2019, Vol. 11, no. 4, pp. 462-477. DOI: 10.15828/2075-8545-2019-11-4-462-477.

Machine-readable information on CC-licenses (HTML-code) in metadata of the paper

$<$ rel="license" href="http://creativecommons.org/licenses/by/4.0/"><img alt="Creative Commons License" style="border-width:0" src="https://i.creativecommons.org/l/by/4.0/88x31.png" / ></a $><$ br / > span xmlns:dct="http://purl.org/dc/terms/" href="http://purl.org/dc/dcmitype/Text" property="dct:title" rel="dct:type" $>$ Experimental study of heat-insulating aerogelbased nanomaterials $</$ span $>$ by $<$ a xmlns:cc="http://creativecommons.org/ns\#" href="Nanotehnologii v stroitel'stve = Nanotechnologies in Construction. 2019, Vol. 11, no. 4, pp. 462-477. DOI: 10.15828/2075-8545-2019-11-4-462-477" property="cc:attributionName" rel="cc:attributionURL">Baikov I.R., Smorodova O.V., Trofimov A.Yu., Kuznetcova E.V. $</$ a $>$ is licensed under a $<$ a rel="license" href="http://creativecommons.org/ licenses/by/4.0/" $>$ Creative Commons Attribution 4.0 International License $</ \mathrm{a}>$. $<$ br $/>$ Based on a work at $<$ a xmlns:dct="http://purl.org/dc/terms/" href="http://nanobuild.ru/en_EN/nanobuild-4-2019/" rel="dct:source">http://nanobuild.ru/en_EN/nanobuild-4-2019/</a $>$.<br/>Permissions beyond the scope of this license may be available at <a xmlns:cc="http://creativecommons.org/ns\#" href="olga_smorodova@mail.ru"rel="cc:morePermissions">olga_smorodova@mail.ru</a> .

The paper has been received by editors: 24.06.2019.

The paper has been received by editors after peer-review: 10.07.2019.

The paper has been accepted for publication: 03.08.2019. 


\title{
Экспериментальное исследование теплоизоляционных наноматериалов на основе аэрогелей
}

\author{
Авторы: \\ Байков Игорь Равильевич, \\ проф., ФГБОУ ВО «Уфимский государственный нефтяной технический университет»; \\ Россия, г. Уфа, Республика Башкортостан, pte.ugntu@rusoil.net \\ Смородова Ольга Викторовна, \\ доцент, ФГБОУ ВО «Уфимский государственный нефтяной технический университет»; \\ Россия, г. Уфа, Республика Башкортостан, olga_smorodova@mail.ru \\ Трофимов Андрей Юрьевич, \\ доцент, ФГБОУ ВО «Уфимский государственный нефтяной технический университет»; \\ Россия, г. Уфа, Республика Башкортостан, trofimov_pte@mail.ru \\ Кузнецова Елена Викторовна, \\ доцент, ФГБОУ ВО «Уфимский государственный нефтяной технический университет»; \\ Россия, г. Уфа, Республика Башкортостан, nsp-rb@mail.ru
}

Резюме: В настоящее время достижения в развитии передовых технологий непосредственно связаны с качеством и технологичностью используемых материалов. К наиболее перспективным относятся аэрогели - наноструктурированные материалы со множеством полезных свойств. Мезопористая структура аэрогелей определяет их широкое применение, как в промышленности, так и в науке.

За период около полувека наноструктурированный материал на основе кремнезема нашел широкое применение во многих направлениях науки и техники. Среди них - тепло- и шумоизоляция, автоматика, химия, медицина, охрана окружающей среды, промышленная и пожарная безопасность, энергетика, аэрокосмическая промышленность, потребительские товары и военные технологии.

В статье рассмотрено экспериментальное исследование теплозащитных свойств теплоизоляционного материала на основе кремнийоксидного аэрогеля - Insuflex. Это гибкий рулонный материал для снижения теплопотерь с поверхности технологического оборудования, трубопроводных систем, отсекающей и регулирующей арматуры. Методом порядковых статистик установлена экспоненциальная зависимость коэффициента теплопроводности аэрогеля от средней температуры образца. Полученные результаты свидетельствуют о возможности энергоэффективного применения материала в системах теплоснабжения и теплопотребления.

Ключевые слова: теплопроводность, тепловая изоляция, аэрогель, моделирование, измерение.

Для цитирования: Байков И.Р., Смородова О.В., Трофимов А.Ю., Кузнецова Е.В. Экспериментальное исследование теплоизоляционных наноматериалов на основе аэрогелей // Нанотехнологии в строительстве. - 2019. - Том 11, № 4. - С. 462-477. DOI: 10.15828/2075-8545-2019-11-4-462-477.

Машиночитаемая информация о СС-лицензиях (HTML-код) в метаданных статьи

$<$ rel="license" href="http://creativecommons.org/licenses/by/4.0/" ><img alt="Creative Commons License" style="border-width:0" src="https://i.creativecommons.org/l/by/4.0/88x31.png" / ></a $><$ br $/><$ span xmlns:dct="http://purl.org/dc/terms/" href="http://purl.org/dc/dcmitype/Text" property="dct:title" rel="dct:type" $>$ Experimental study of heat-insulating aerogelbased nanomaterials $</$ span $>$ by $<$ a xmlns:cc="http://creativecommons.org/ns\#" href="Nanotehnologii v stroitel'stve = Nanotechnologies in Construction. 2019, Vol. 11, no. 4, pp. 462-477. DOI: 10.15828/2075-8545-2019-11-4-462-477" property="cc:attributionName" rel="cc:attributionURL" >Baikov I.R., Smorodova O.V., Trofimov A.Yu., Kuznetcova E.V. $</$ a $>$ is licensed under a $<$ a rel="license" href="http://creativecommons.org/ licenses/by/4.0/" $>$ Creative Commons Attribution 4.0 International License $</ \mathrm{a}>$. <br $/>$ Based on a work at $<$ a xmlns:dct="http://purl.org/dc/terms/" href="http://nanobuild.ru/en_EN/nanobuild-4-2019/" rel="dct:source" >http://nanobuild.ru/en_EN/nanobuild-4-2019/</a $>$. <br / >Permissions beyond the scope of this license may be available at <a xmlns:cc="http://creativecommons.org/ns\#" href="olga_smorodova@mail.ru" rel="cc:morePermissions">olga_smorodova@@ail.ru</a > .

Статья поступила в редакцию: 24.06.2019.

Статья поступила в редакцию после рецензирования: 10.07.2019.

Статья принята к публикации: 03.08.2019. 


\section{INTRODUCTION}

$\mathrm{A}^{\mathrm{l}}$ lot of modern research is concentrated in the development of new materials [1]. Of greatest interest is the group of nanostructured airgels [2]. By 2019, quartz, amorphous silica, carbon, and silica with gadolinium and terbium additives [3], aerogels based on oxides of zinc, chromium, tin, tungsten, iron with aluminum additives, etc. were obtained in the world [4].

The material of the airgel class is a lattice of interconnected nanofibers or nanotubes [5]. This is a special cluster of substances with high porosity, specific surface area, small size of solid particles, and openwork structure of a solid skeleton [6]. Aerogels were first synthesized by S. Kistler (USA) in the early 30s of the twentieth century [2]. The first airgel samples were obtained on the basis of silicon dioxide, oxides of aluminum, tungsten, iron, tin, etc. [7, 8]

In the gel family, airgel based on $\mathrm{SiO}_{2}$ is of interest both from the point of view of scientific study and for practical use $[9,10]$. Its gross production exceeds one third of the global synthesis of nanomaterials [11]. Silicon oxide airgel has a stochastic fractal structure, which is determined by the structure and nature of the bonds between silicon oxide bridges $(\mathrm{O}-\mathrm{Si}-\mathrm{O}-\mathrm{Si}-\mathrm{O})$ [12]. The special properties of the airgel are due to the high specific pore volume (up to $99 \%$ of the volume) with sizes from $5 \mathrm{~nm}$ to $100 \mathrm{~nm}$ each [13].

In the table 1 the main technical characteristics of silica $\mathrm{SiO}_{2}$ airgel based on studies of the Lawrence Livermore National Laboratory (USA) are shown [14, 15].

\section{MAIN PART}

\section{The relevance of the task}

Airgels with low thermal conductivity are used as heatinsulating, heat- and fire-retardant, sound-insulating, structural, filtering materials, etc. [17]. Thermal protection based on them is increasingly used in refrigeration technologies for tanks with liquefied hydrocarbons [18].

Table 1

Technical characteristics of silica $\mathrm{SiO}_{2}$ airgel [16]

\begin{tabular}{|c|l|l|}
\hline № & Name of indicator & Value of indicator \\
\hline 1 & Composition & $\begin{array}{l}\text { hydrophobic type }-95 \% \mathrm{SiO}_{2}, \sim 4 \% \mathrm{C}, \sim 1 \% \mathrm{H} \\
\text { hydrophilic type }-99,6 \% \mathrm{SiO}_{2}, \sim 0,4 \% \mathrm{H}\end{array}$ \\
\hline 2 & Density, $\mathrm{kg} / \mathrm{m}^{3}$ & $4 \ldots 600$ \\
\hline 3 & Porosity, $\%$ & $73 \ldots 99,8$ \\
\hline 4 & The thickness of the fibers, $\mathrm{nm}$ & $2 \ldots 3$ \\
\hline 5 & Specific surface area, $\mathrm{m}^{2} / \mathrm{g}$ & $580 \ldots 960$ \\
\hline 6 & Coefficient of thermal expansion, $\mathrm{cm} / \mathrm{cm}$ & $\sim 2 \times 10^{-6}($ at $293 \ldots 353 \mathrm{~K})$ \\
\hline 7 & Thermal conductivity, $\mathrm{W} /(\mathrm{mK})$ & $0,016 \ldots 0,030$ \\
\hline 8 & Melting point, $\mathrm{K}$ & $\sim 1473$ \\
\hline 9 & Use temperature, $\mathrm{K}$ & $3 \ldots 650$ \\
\hline
\end{tabular}

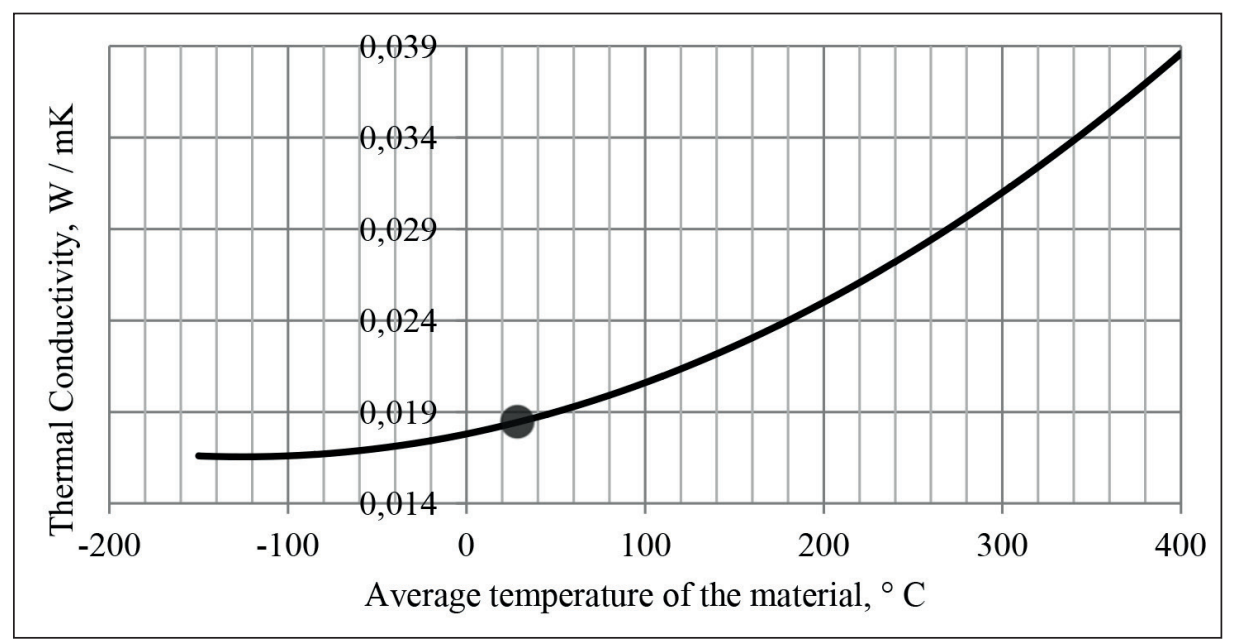

Fig. 1. The dependence of the coefficient of thermal conductivity of the airgel on the average temperature of the material according to the manufacturer

- - result of measurements by the authors 
The authors' studies [18] showed that the total thermal conductivity of the airgel slightly depends on the properties of the material frame. In this case, heat transfer by heat conduction between granules and nanofibers plays a decisive role at low operating environmental parameters. At high temperatures, the bulk of the thermal energy is transferred in a radiant manner. The convective heat transfer in nanopores and capillaries with a diameter of less than $2 \mathrm{~mm}$ is negligible in view of the impossibility of forming free convection flows [19]. Many authors have experimentally confirmed that the overall thermal conductivity of materials based on airgel significantly depends on the properties of the gas filling the pores and capillaries, humidity, and the diameter of the nanopores.

Studies conducted on airgels $[20,21]$ show that thermal conductivity decreases with decreasing material temperature (Fig. 1).

In this case, the minimum values $\square$ 回 of the coefficient of thermal conductivity are achieved in the zone of deep negative temperatures. This indicates the particular effectiveness of the aerogels use in the cryogenic region of the operating parameters.

\section{Experimental part}

This work is devoted to the justification of the heatshielding properties of airgel material in the temperature range of operation of heat supply systems. An experimental study of the thermal insulation properties of the airgel was carried out on samples of industrial thermal insulation made on the basis of fiberglass. This is a rolled material for coating technological equipment, pipelines, shutoff and control valves in order to reduce heat loss [22]. The thickness of the material in the roll is $10 \mathrm{~mm}$ (Fig. 2a). The accuracy of the experiment was ensured by the organization of measurements on samples of two types - in 2 and 3 layers of material, i.e. total thickness of 20 and $30 \mathrm{~mm}$.

To measure the thermal conductivity of the material, the ITP-MG4 «250» device was used (Fig. 2b).

The device is designed to measure indicators of the intensity of heat transfer by thermal conductivity:

- thermal conductivity coefficient, $\lambda, \mathrm{W} / \mathrm{mK}$;

- thermal resistance, $\mathrm{R}, \mathrm{m}^{2} \mathrm{~K} / \mathrm{W}$.

The instrument options allow you to conduct an experiment either in stationary mode or by using a heat probe.

In the experiment, the thermal conductivity and thermal resistance of the material were determined at an average sample temperature of $+15^{\circ}$ to $+42.5^{\circ} \mathrm{C}$. The temperature control of the refrigerator and heater and their temperature control were carried out automatically.

The main technical characteristics of the device are given in table 2.

During measurements, a stationary heat flux through a flat sample is created. In the experiment, the thickness of the sample, the density of the heat flux, and the temperature of the faces of the sample are recorded.

To ensure the stability of heat transfer in the device, a control unit for the heater and the refrigerator is made on Peltier elements, a heat meter, and platinum thermocouples. The cooling of the Peltier elements is organized by a fan.

The measurements were carried out in a stationary mode on samples of different thicknesses at different temperatures of the heater and refrigerator in the entire range of operating temperatures of the device. The temperature difference between the heater and the refrigerator was maintained in the range of $35-40^{\circ} \mathrm{C}$. The results of measurements of the thermal conductivity of the material for a sample $30 \mathrm{~mm}$ thick are given in table 3 , for a sample $20 \mathrm{~mm}$ thick - in table 4 .

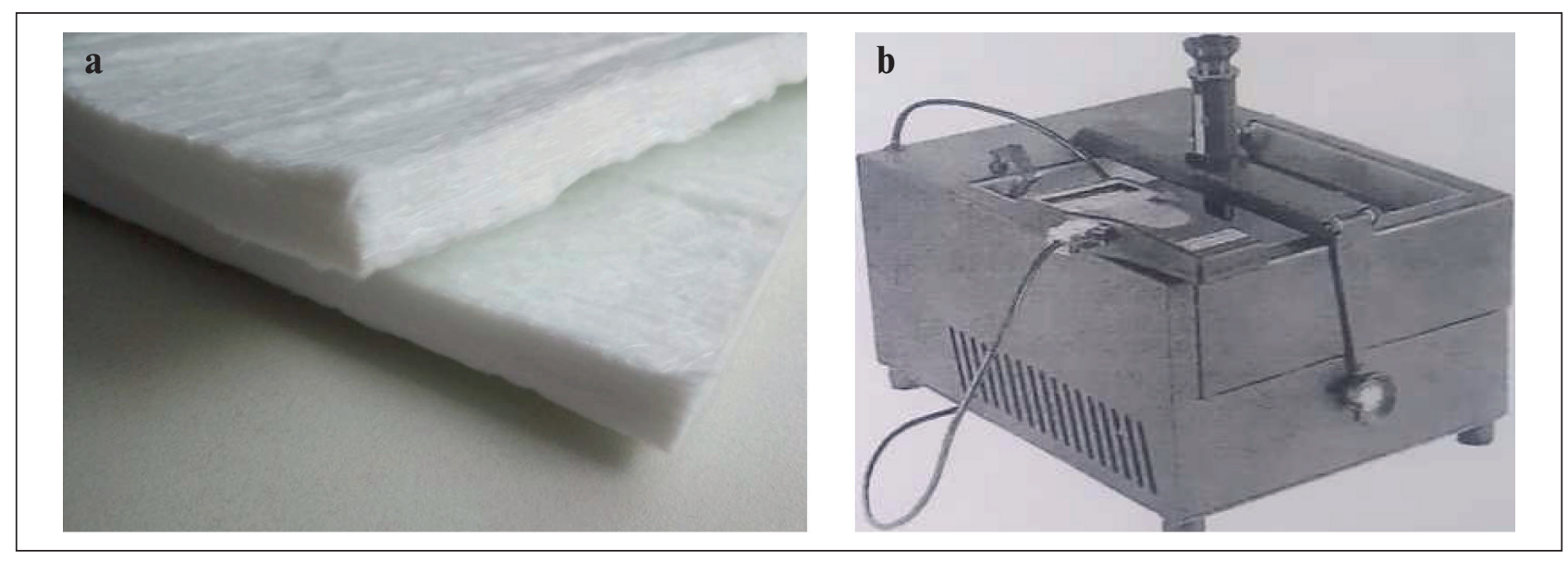

Fig. 2. Organization of an experimental study of airgel material

$\mathrm{a}-$ heat insulation based on airgel Insuflex; $\mathrm{b}$ - heat meter ITP-MG4 «250» 
Table 2

Technical characteristics of ITP-MG4 «250»

\begin{tabular}{|c|l|l|}
\hline$№$ & Name of indicator & Value of indicator \\
\hline 1 & Range of measurement of the coefficient of thermal conductivity in stationary mode, W/mK & $0,01 \ldots 1,5$ \\
\hline 2 & Range of measurement of thermal resistance, $\mathrm{m}^{2} \mathrm{~K} / \mathrm{W}$ & $0,01 \ldots 1,5$ \\
\hline 3 & Range of measurement of thermal conductivity by the method of a heat probe, W/mK & $0,03 \ldots 1$ \\
\hline 4 & $\begin{array}{l}\text { The limit of the main relative error in determining the coefficient of thermal } \\
\text { conductivity and thermal resistance in stationary mode, } \%\end{array}$ & \pm 5 \\
\hline 5 & $\begin{array}{l}\text { The limit of the main relative error in determining the coefficient of thermal } \\
\text { conductivity and thermal resistance in stationary mode, } \%\end{array}$ & \pm 7 \\
\hline 6 & Sizes of the test sample, mm & $250 \times 250 \times 5 . .50$ \\
\hline Time of one measurement, no more, min: & 120 \\
\hline 7 & - in stationary mode & 10 \\
\hline 8 & - by a method of a thermal probe \\
\hline
\end{tabular}

Table 3

Measurement results on a sample $30 \mathrm{~mm}$ thick

\begin{tabular}{|c|c|c|c|c|}
\hline \multirow{4}{*}{ Test number } & \multicolumn{3}{|c|}{ Material Surface Temperature } & \multirow{2}{*}{$\begin{array}{c}\text { Thermal } \\
\text { conductivity }\end{array}$} \\
\hline & cold & heated & medium & \\
\hline & $t_{\mathrm{x}}$ & $t_{H}$ & $t_{\mathrm{cp}}$ & $\lambda$ \\
\hline & ${ }^{\circ} \mathbf{C}$ & ${ }^{\circ} \mathrm{C}$ & ${ }^{\circ} \mathbf{C}$ & $\mathbf{W} / \mathbf{m} \times \mathbf{K}$ \\
\hline № 1 & -1 & 35 & 17 & 0,017 \\
\hline № 2 & 0 & 36 & 18 & 0,018 \\
\hline № 3 & 1 & 37 & 19 & 0,018 \\
\hline № 4 & 2 & 38 & 20 & 0,018 \\
\hline № 5 & 3 & 39 & 21 & 0,020 \\
\hline № 6 & 4 & 40 & 22 & 0,020 \\
\hline № 7 & 5 & 41 & 23 & 0,020 \\
\hline № 8 & 6 & 42 & 24 & 0,019 \\
\hline № 9 & 7 & 43 & 25 & 0,018 \\
\hline № 10 & 8 & 44 & 26 & 0,020 \\
\hline № 11 & 9 & 45 & 27 & 0,019 \\
\hline № 12 & 10 & 46 & 28 & 0,018 \\
\hline № 13 & 11 & 47 & 29 & 0,018 \\
\hline № 14 & 12 & 48 & 30 & 0,018 \\
\hline № 15 & 13 & 49 & 31 & 0,019 \\
\hline № 16 & 14 & 50 & 32 & 0,018 \\
\hline № 17 & 15 & 51 & 33 & 0,018 \\
\hline № 18 & 16 & 52 & 34 & 0,019 \\
\hline № 19 & 17 & 53 & 35 & 0,018 \\
\hline № 20 & 18 & 54 & 36 & 0,018 \\
\hline № 21 & 19 & 55 & 37 & 0,018 \\
\hline № 22 & 20 & 56 & 38 & 0,018 \\
\hline № 23 & 21 & 57 & 39 & 0,018 \\
\hline № 24 & 22 & 58 & 40 & 0,018 \\
\hline № 25 & 23 & 59 & 41 & 0,018 \\
\hline № 26 & 24 & 60 & 42 & 0,020 \\
\hline
\end{tabular}


Table 4

Measurement results on a sample $20 \mathrm{~mm}$ thick

\begin{tabular}{|c|c|c|c|c|}
\hline \multirow{2}{*}{ Test number } & \multicolumn{3}{|c|}{ Material Surface Temperature } & \multirow{2}{*}{$\begin{array}{c}\text { Thermal } \\
\text { conductivity }\end{array}$} \\
\cline { 2 - 4 } & $\mathbf{c o l d}$ & heated & medium & $\boldsymbol{\lambda}$ \\
\cline { 2 - 4 } & $\mathbf{t}_{\mathbf{x}}$ & $\mathbf{t}_{\mathbf{H}}$ & $\mathbf{t}_{\mathbf{c p}}$ & $\mathbf{W} / \mathbf{m} \times \mathbf{K}$ \\
\cline { 2 - 4 } & ${ }^{\circ} \mathbf{C}$ & ${ }^{\circ} \mathbf{C}$ & ${ }^{\circ} \mathbf{C}$ & 0,018 \\
\hline № 1 & -1 & 35 & 17 & 0,018 \\
\hline № 2 & 2 & 38 & 20 & 0,018 \\
\hline № 3 & 4 & 40 & 22 & 0,018 \\
\hline № 4 & 6 & 42 & 24 & 0,018 \\
\hline № 5 & 8 & 44 & 26 & 0,018 \\
\hline № 6 & 10 & 46 & 28 & 0,018 \\
\hline № 7 & 12 & 48 & 30 & 0,018 \\
\hline № 8 & 14 & 50 & 32 & 0,018 \\
\hline № 9 & 16 & 52 & 34 & 0,018 \\
\hline № 10 & 18 & 54 & 36 & 0,019 \\
\hline № 11 & 20 & 56 & 38 & 0,019 \\
\hline № 12 & 22 & 58 & 40 & \\
\hline
\end{tabular}

\section{Analysis of the results}

The results obtained during the measurements showed that the experimental value of the thermal conductivity of the insulating material lies in a rather narrow range of values $\square(0,017 \ldots 0,02) \mathrm{W} / \mathrm{mK}$ with high repeatability of $0,018 \mathrm{~W} / \mathrm{mK}$. Therefore, an assumption was made about the normal law of distribution of thermal conductivity values $\square$ ( $\square$ for the range of average temperatures of the material $(17 \ldots 42)^{\circ} \mathrm{C}$.

To confirm this hypothesis [23] according to the results of measurements carried out on a sample $30 \mathrm{~mm}$ thick, a histogram of the relative frequencies of thermal conductivity hitting values $\mathbf{Q}^{\mathrm{Q}}$ was plotted as a function of the average value in the interval for three sub-intervals, shown in Fig. 3. The sample size was 26 values, the subinterval length was $0.001 \mathrm{~W} / \mathrm{mK}$. The sample average value for this sample, taking into account the relative frequency, was $0,0188 \mathrm{~W} / \mathrm{mK}$. For such a distribution, the sample standard deviation is $\sigma=5,49 \times 10^{-4}$.

The calculated value of the Pearson $\chi^{2}$ consent criterion is identified at 0,065 , which indicates a low reliability of the accepted hypothesis. This is due to the influence of the average temperature on the thermal conductivity of the material, which is significant for the studied temperature range.

The dependence of the thermal conductivity of the material on the average temperature of the sample is

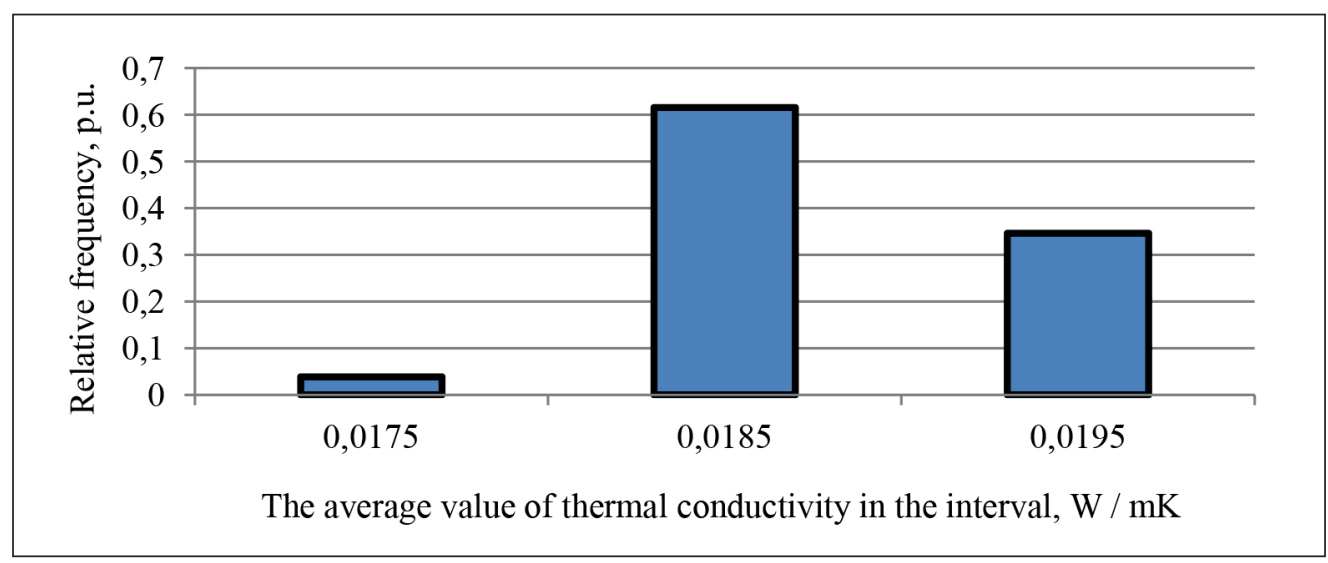

Fig. 3. Relative frequency histogram 


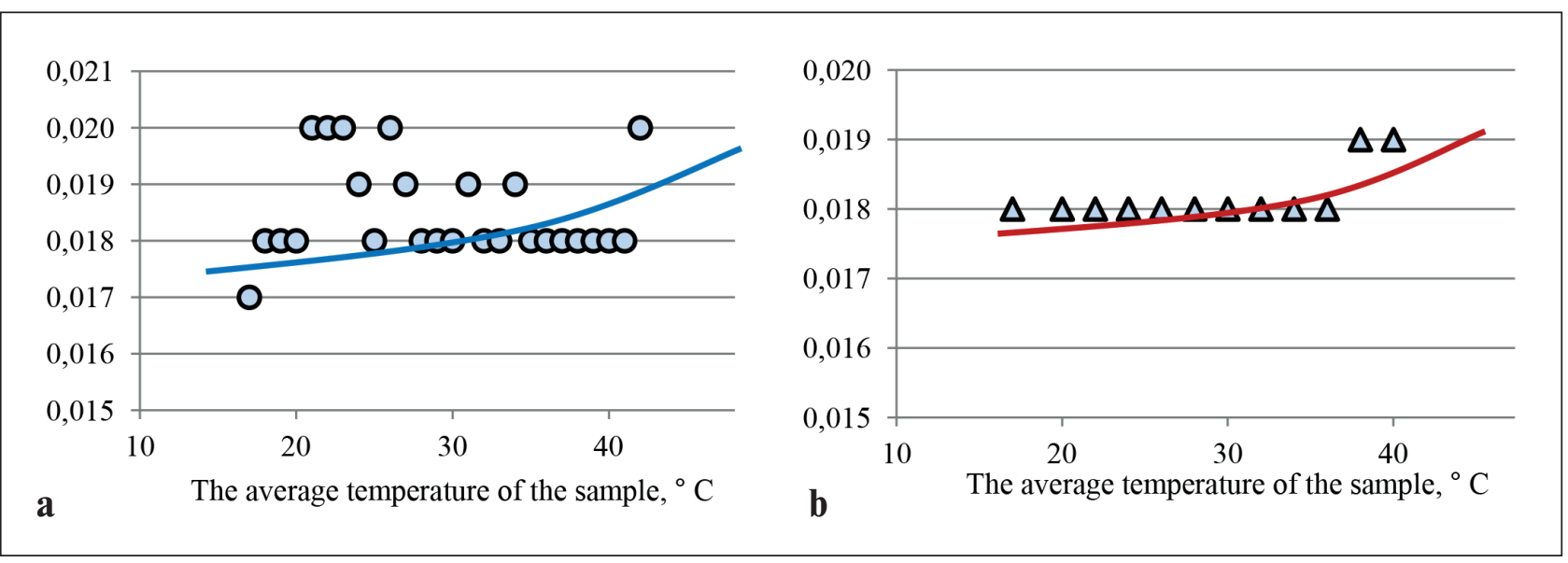

Fig. 4. The dependence of the thermal conductivity of the material on the average temperature of the airgel sample $\mathrm{a}$ - sample thickness $30 \mathrm{~mm}$; b - sample thickness $20 \mathrm{~mm}$

shown in Fig. 4a and Fig. 4b. The solid line in the figures shows the dependence of the thermal conductivity of the material on temperature according to the manufacturer of thermal insulation. In general, the presented results confirm the data on the thermal insulation properties of the airgel, declared by the manufacturer of this material (marker in Fig. 1).

At the same time, on the sample with a thickness of $20 \mathrm{~mm}$, a fairly clear increasing dependence of thermal conductivity on temperature is observed, which corresponds to the data of the manufacturer of thermal insulation material.

The results obtained on a sample $30 \mathrm{~mm}$ thick have a sufficient amount of noise interference, which prevented a more accurate determination of the desired value.
Building a model for data with a large spread gives an approximate solution with a low confidence value. To increase the accuracy of determining the dependence, we used the method of ordinal statics or the ordinal approximation of a monotonic dependence [23]. Moreover, from the obtained experimental data, the monotonic dependence is restored, in accordance with a previously known distribution law. In particular, for thermal conductivity this is a monotonically increasing function. The result of applying the method of ordinal statics for experimental data obtained on a sample $30 \mathrm{~mm}$ thick is shown in Fig. 5. These results have a higher confidence value compared to the initial data, which confirms the effectiveness of this method for the restoration of monotonic dependencies.

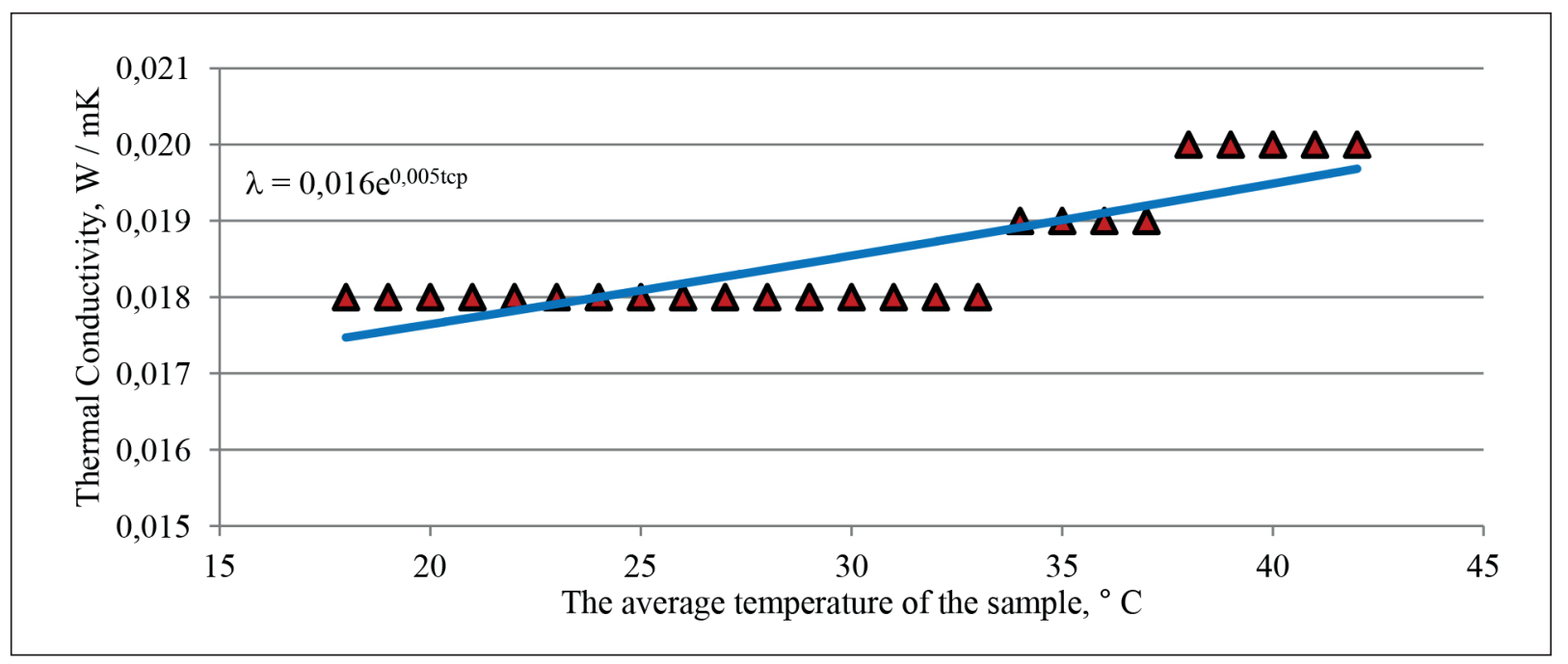

Fig. 5. The dependence of the coefficient of thermal conductivity of the airgel on average temperature restored by the method of ordinal statics 


\section{CONCLUSION}

1. The average value of the coefficient of thermal conductivity of a thermal insulation material based on silicon oxide airgel - Insuflex - at the level of $0,0185 \mathrm{~W} / \mathrm{mK}$, which is significantly lower than similar indicators for other thermal insulation materials in the temperature regime of heat supply systems, has been experimentally established.
2. An equation of one-parameter regression of the dependence of the thermal conductivity coefficient of airgel thermal insulation on the average temperature of the material is obtained.

3. The low value of the coefficient of thermal conductivity of the material indicates its high energy efficiency. The use of thermal insulation based on airgel will reduce heat loss by no less than $47 \%$ compared with the used heat-insulating materials.

\section{ВВЕДЕНИЕ}

$\mathrm{M}$ ножество современных исследований сконцентрировано в сфере разработки новых материалов [1]. Наибольший интерес вызывает группа наноструктурных аэрогелей [2]. К 2019 г. в мире получены кварцевый, аморфный кремнеземный, углеродный, кремнеземный с добавками гадолиния и тербия [3], аэрогели на основе оксидов цинка, хрома, олова, вольфрама, железа с алюминиевыми добавками и пр. [4].

Материал класса аэрогелей представляет собой решетку из связанных между собой нановолокон или нанотрубок [5]. Это особый кластер веществ с высокой пористостью, удельной поверхностью, малым размером твердых частиц и ажурной структурой твердого каркаса [6]. Впервые аэрогели были синтезированы С. Кистлером (США) в начале 30-х годов XX века [2]. Первые образцы аэрогеля были получены на основе двуокиси кремния, оксидов алюминия, вольфрама, железа, олова и др. [7, 8]

В семействе гелей аэрогель на основе $\mathrm{SiO}_{2}$ вызывает интерес как с точки зрения научного изу- чения, так и для практического использования $[9,10]$. Его валовое производство превышает третью часть от мирового синтеза наноматериалов [11]. Кремнийоксидный аэрогель имеет стохастическую фрактальную структуру, определяемую строением и характером связей между кремнийоксидными мостиками $(\mathrm{O}-\mathrm{Si}-\mathrm{O}-\mathrm{Si}-\mathrm{O})$ [12]. Особые свойства аэрогеля обусловлены высоким удельным объемом пор (до 99\% объема) с размерами каждой от 5 до 100 нм [13].

В табл. 1 приведены основные технические характеристики кремнеземного $\mathrm{SiO}_{2}$-аэрогеля на основе исследований Ливерморской национальной лаборатории им.Лоуренса (США) [14, 15].

\section{ОСНОВНАЯ ЧАСТЬ}

\section{Актуальность задачи}

Аэрогели с низкой теплопроводностью находят применение в качестве теплоизоляционных, тепло- и огнезащитных, звукоизоляционных, конструкционных, фильтрующих материалов и пр. [17]. Те-

\section{Таблица 1}

Технические характеристики кремнеземного $\mathrm{SiO}_{2}$-аэрогеля [16]

\begin{tabular}{|c|c|c|}
\hline № $\pi / \Pi$ & Наименование показателя & Значение показателя \\
\hline 1 & Состав & $\begin{array}{l}\text { гидрофобный тип - 95\% } \mathrm{SiO}_{2}, \sim 4 \% \mathrm{C}, \sim 1 \% \mathrm{H} \\
\text { гидрофильный тип }-99,6 \% \mathrm{SiO}_{2}, \sim 0,4 \% \mathrm{H}\end{array}$ \\
\hline 2 & Плотность, кг $/ \mathrm{M}^{3}$ & $4 \ldots 600$ \\
\hline 3 & Пористость, \% & $73 \ldots 99,8$ \\
\hline 4 & Толщина волокон, нм & $2 \ldots 3$ \\
\hline 5 & Площадь удельной поверхности, м²/г & $580 \ldots 960$ \\
\hline 6 & Коэффициент термического расширения, см/см & 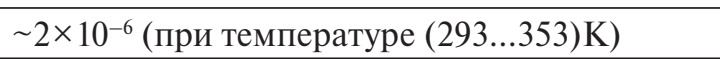 \\
\hline 7 & Коэффициент теплопроводности, Вт/(мК) & $0,016 \ldots 0,030$ \\
\hline 8 & Температура плавления, K & $\sim 1473$ \\
\hline 9 & Температура применения, K & $3 \ldots 650$ \\
\hline
\end{tabular}




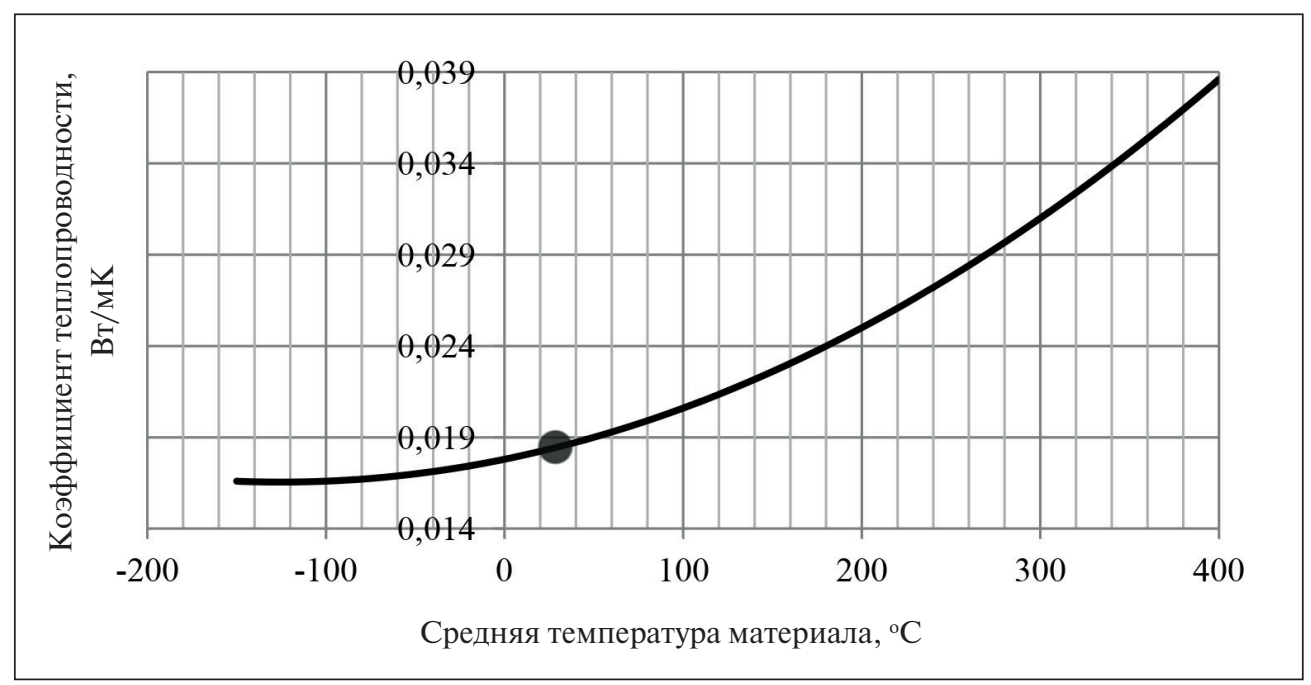

Рис.1. Зависимость коэффициента теплопроводности аэрогеля от средней температуры материала по сведениям производителя

- - результат измерений авторами

пловая защита на их основе все шире используются в холодильных технологиях для емкостей со сжиженными углеводородами [18].

Исследования авторов [18] показали, что общая теплопроводность аэрогеля незначительно зависит от свойств каркаса материала. При этом теплообмен теплопроводностью между гранулами и нановолокнами играет определяющую роль при невысоких режимных параметрах окружающей среды. При высоких температурах основная доля тепловой энергии переносится лучистым способом. Конвективный перенос теплоты в нанопорах и капиллярах диаметром менее 2 мм пренебрежимо мал в виду невозможности формирования потоков свободной конвекции [19]. Многими авторами экспериментально было подтверждено, что общая теплопроводность материалов на основе аэрогеля значительно зависит от свойств газа, заполняющего поры и капилляры, влажности окружающей среды и диаметра нанопор.

Исследования, проведенные на аэрогелях [20, 21], показывают, что с понижением температуры материала уменьшается теплопроводность (рис. 1).

При этом минимальные значения коэффициента теплопроводности достигаются в зоне глубоких отрицательных температур. Это свидетельствует об особой эффективности применения аэрогелей в криогенной области параметров эксплуатации.

\section{Экспериментальная часть}

Настоящая работа посвящена обоснованию теплозащитных свойств аэрогелевого материала в диапазоне температур эксплуатации систем те- плоснабжения. Экспериментальное исследование теплоизоляционных свойств аэрогеля проводилось на образцах промышленной тепловой изоляции, выполненной на основе стеклохолста. Это рулонный материал для покрытия технологического оборудования, трубопроводов, запорной и регулирующей арматуры с целью снижения потерь тепловой энергии [22]. Толщина материала в рулоне составляет 10 мм (рис. 2a). Точность проведения эксперимента была обеспечена организацией измерений на образцах двух видов - в 2 и в 3 слоя материала, т.е. полной толщиной 20 и 30 мм.

Для измерения коэффициента теплопроводности материала было использовано устройство ИТП-МГ4 «250» (рис. 2б).

Прибор предназначен для измерения показателей интенсивности теплообмена теплопроводностью:

- коэффициента теплопроводности, $\lambda$, Вт/мК;

- термического сопротивления, $\mathrm{R}, \mathrm{M}^{2} \mathrm{~K} / \mathrm{B}$.

Опции прибора позволяют проводить эксперимент либо при стационарном режиме, либо методом теплового зонда.

В эксперименте определялась теплопроводность и термическое сопротивление материала при средней температуре образца от $+15^{\circ}$ до $+42,5^{\circ} \mathrm{C}$. Регулирование температур холодильника и нагревателя и их термостатирование выполнялось автоматически.

Основные технические характеристики прибора приведены в табл. 2.

При проведении измерений создается стационарный тепловой поток через плоский образец. В эксперименте фиксируется толщина образца, плотность теплового потока и температуры граней образца. 

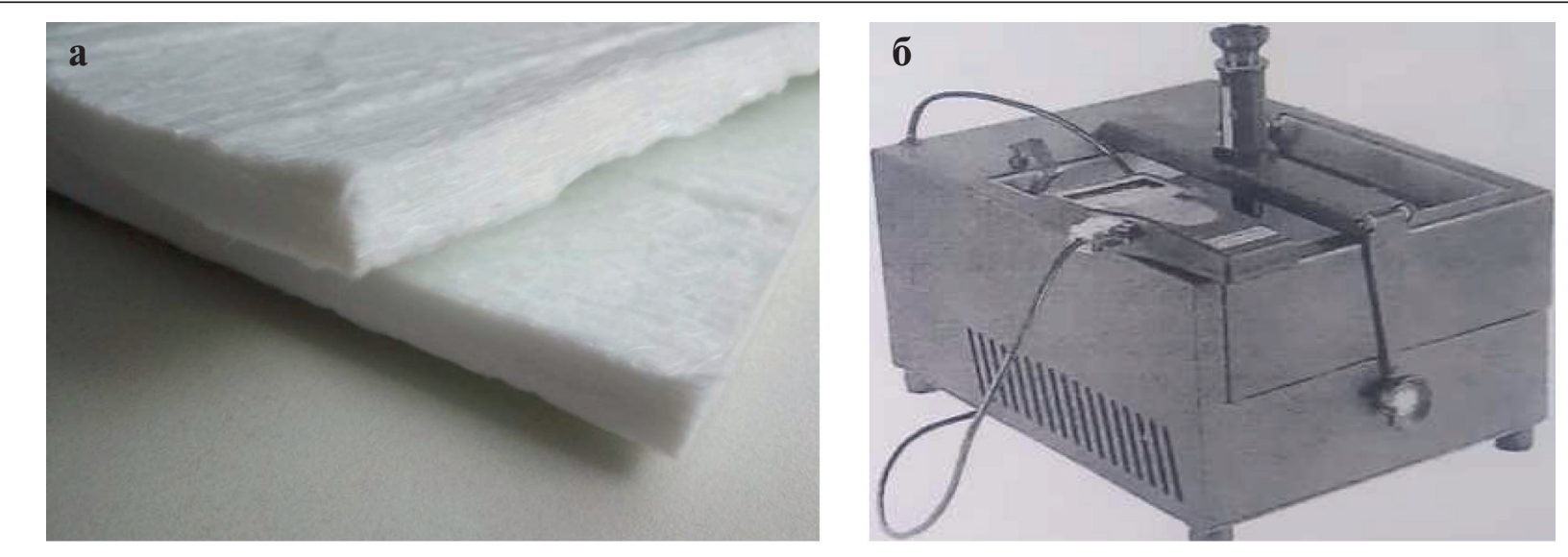

Рис. 2. Организация экспериментального исследования аэрогельного материала

a - тепловая изоляция на основе аэрогеля Insuflex; б - измеритель теплопроводности ИТП-МГ4«250»

Таблица 2

Технические характеристики ИТП-МГ4 «250»

\begin{tabular}{|c|l|l|}
\hline $\begin{array}{c}\text { № } \\
\text { п/п }\end{array}$ & Наименование характеристик & $\begin{array}{l}\text { Значение } \\
\text { характеристик }\end{array}$ \\
\hline 1 & $\begin{array}{l}\text { Диапазон измерения коэффициента теплопроводности при стационарном } \\
\text { режиме, Вт/м К }\end{array}$ & $0,01 \ldots 1,5$ \\
\hline 2 & Диапазон измерения термического сопротивления, м²К/Вт & $0,01 \ldots 1,5$ \\
\hline 3 & Диапазон измерения теплопроводности методом теплового зонда, Вт/мК & $0,03 \ldots 1$ \\
\hline 4 & $\begin{array}{l}\text { Предел основной относительной погрешности определения коэффициента } \\
\text { теплопроводности и термического сопротивления при стационарном режиме, } \%\end{array}$ & \pm 5 \\
\hline 5 & $\begin{array}{l}\text { Предел основной относительной погрешности определения коэффициента } \\
\text { теплопроводности методом теплового зонда, } \%\end{array}$ & \pm 7 \\
\hline 6 & Размеры испытываемого образца, мм & $250 \times 250 \times 5 . .50$ \\
\hline Время одного измерения, не более, мин: & 120 \\
\hline 7 & - при стационарном режиме & 10 \\
\hline 8 & - методом теплового зонда & \multicolumn{2}{|l}{} \\
\hline
\end{tabular}

Для обеспечения стационарности теплообмена в устройстве предусмотрен блок управления нагревателем и холодильником, выполненный на элементах Пельтье, тепломер, платиновые термопары. Охлаждение элементов Пельтье организовано вентилятором.

Измерения производились в стационарном режиме на образцах разной толщины при различных температурах нагревателя и холодильника во всем диапазоне рабочих температур прибора. Разница температур между нагревателем и холодильником поддерживалась в диапазоне $35-40^{\circ} \mathrm{C}$. Результаты измерений коэффициента теплопроводности материала для образца толщиной 30 мм приведены в табл. 3, для образца толщиной 20 мм - в табл. 4.

\section{Анализ полученных результатов}

Результаты, полученные в ходе измерений, показали, что экспериментальное значение теплопроводности теплоизоляционного материала лежит в достаточно узком диапазоне значений $(0,017 \ldots 0,02)$ Вт/мК при высокой повторяемости значения 0,018 Вт/мК. Следовательно, было сделано предположение о нормальном законе распределения значений теплопроводности для диапазона средних температур материала $(17 \ldots 42)^{\circ} \mathrm{C}$.

Для подтверждения данной гипотезы [23] по результатам измерений, проведенных на образце толщиной 30 мм, была построена гистограмма относительных частот попадания значений теплопро- 
POWER ENGINEERING NANOTECHNOLOGIES • HAHOTEXНОЛОГИИ В ЭНЕРГETИКE

Таблица 3

Результаты измерений на образце толщиной 30 мм

\begin{tabular}{|c|c|c|c|c|}
\hline \multirow{4}{*}{ Номер опыта } & \multicolumn{3}{|c|}{ Температура поверхности материала } & \multirow{2}{*}{$\begin{array}{c}\text { Коэффициент } \\
\text { теплопрово- } \\
\text { дности }\end{array}$} \\
\hline & холодной & нагреваемой & средней & \\
\hline & $t_{x}$ & $\mathbf{t}_{\mathrm{H}}$ & $t_{c p}$ & $\lambda$ \\
\hline & ${ }^{\circ} \mathbf{C}$ & ${ }^{\circ} \mathrm{C}$ & ${ }^{\circ} \mathrm{C}$ & Вт $/ \mathbf{M} \times \mathbf{K}$ \\
\hline № 1 & -1 & 35 & 17 & 0,017 \\
\hline № 2 & 0 & 36 & 18 & 0,018 \\
\hline № 3 & 1 & 37 & 19 & 0,018 \\
\hline № 4 & 2 & 38 & 20 & 0,018 \\
\hline № 5 & 3 & 39 & 21 & 0,020 \\
\hline № 6 & 4 & 40 & 22 & 0,020 \\
\hline № 7 & 5 & 41 & 23 & 0,020 \\
\hline № 8 & 6 & 42 & 24 & 0,019 \\
\hline № 9 & 7 & 43 & 25 & 0,018 \\
\hline № 10 & 8 & 44 & 26 & 0,020 \\
\hline № 11 & 9 & 45 & 27 & 0,019 \\
\hline № 12 & 10 & 46 & 28 & 0,018 \\
\hline № 13 & 11 & 47 & 29 & 0,018 \\
\hline № 14 & 12 & 48 & 30 & 0,018 \\
\hline № 15 & 13 & 49 & 31 & 0,019 \\
\hline № 16 & 14 & 50 & 32 & 0,018 \\
\hline № 17 & 15 & 51 & 33 & 0,018 \\
\hline № 18 & 16 & 52 & 34 & 0,019 \\
\hline № 19 & 17 & 53 & 35 & 0,018 \\
\hline № 20 & 18 & 54 & 36 & 0,018 \\
\hline № 21 & 19 & 55 & 37 & 0,018 \\
\hline № 22 & 20 & 56 & 38 & 0,018 \\
\hline № 23 & 21 & 57 & 39 & 0,018 \\
\hline № 24 & 22 & 58 & 40 & 0,018 \\
\hline № 25 & 23 & 59 & 41 & 0,018 \\
\hline № 26 & 24 & 60 & 42 & 0,020 \\
\hline
\end{tabular}

водности в зависимости от среднего значения в интервале для трех подынтервалов, представленная на рис. 3. Объем выборки составил 26 значений, длина подынтервала - 0,001 Вт/мК. Выборочное среднее значение для данной выборки с учетом относительной частоты составило 0,0188 Вт/мК. Для такого распределения выборочное среднеквадратичное отклонение составило $\sigma=5,49 \times 10^{-4}$.

Расчетное значение критерия согласия Пирсона $\chi^{2}$ идентифицировано на уровне 0,065 , что свидетельствует о низкой достоверности принятой гипотезы. Это связано с влиянием средней температуры на те- плопроводность материала, которая для изученного диапазона температур существенна.

Зависимость коэффициента теплопроводности материала от средней температуры образца представлена на рис. 4а и 4б. Сплошной линией на рисунках показана зависимость коэффициента теплопроводности материала от температуры по данным изготовителя тепловой изоляции. В целом, представленные результаты подтверждают данные по теплоизоляционным свойствам аэрогеля, заявленные изготовителем данного материала (маркер на рис. 1). 
POWER ENGINEERING NANOTECHNOLOGIES • HAHOTEXНОЛОГИИ В ЭНЕРГETИКE

Таблица 4

Результаты измерений на образце толщиной 20 мм

\begin{tabular}{|c|c|c|c|c|}
\hline \multirow{4}{*}{ Номер опыта } & \multicolumn{3}{|c|}{ Температура поверхности материала } & \multirow{2}{*}{$\begin{array}{c}\text { Коэффициент } \\
\text { теплопрово- } \\
\text { дности }\end{array}$} \\
\hline & холодной & нагреваемой & средней & \\
\hline & $t_{x}$ & $\mathbf{t}_{\mathrm{H}}$ & $\mathbf{t}_{\mathrm{cp}}$ & $\lambda$ \\
\hline & ${ }^{\circ} \mathrm{C}$ & ${ }^{\circ} \mathbf{C}$ & ${ }^{\circ} \mathrm{C}$ & Вт $/ \mathbf{M} \times \mathbf{K}$ \\
\hline № 1 & -1 & 35 & 17 & 0,018 \\
\hline № 2 & 2 & 38 & 20 & 0,018 \\
\hline № 3 & 4 & 40 & 22 & 0,018 \\
\hline № 4 & 6 & 42 & 24 & 0,018 \\
\hline № 5 & 8 & 44 & 26 & 0,018 \\
\hline № 6 & 10 & 46 & 28 & 0,018 \\
\hline № 7 & 12 & 48 & 30 & 0,018 \\
\hline № 8 & 14 & 50 & 32 & 0,018 \\
\hline № 9 & 16 & 52 & 34 & 0,018 \\
\hline № 10 & 18 & 54 & 36 & 0,018 \\
\hline № 11 & 20 & 56 & 38 & 0,019 \\
\hline № 12 & 22 & 58 & 40 & 0,019 \\
\hline
\end{tabular}

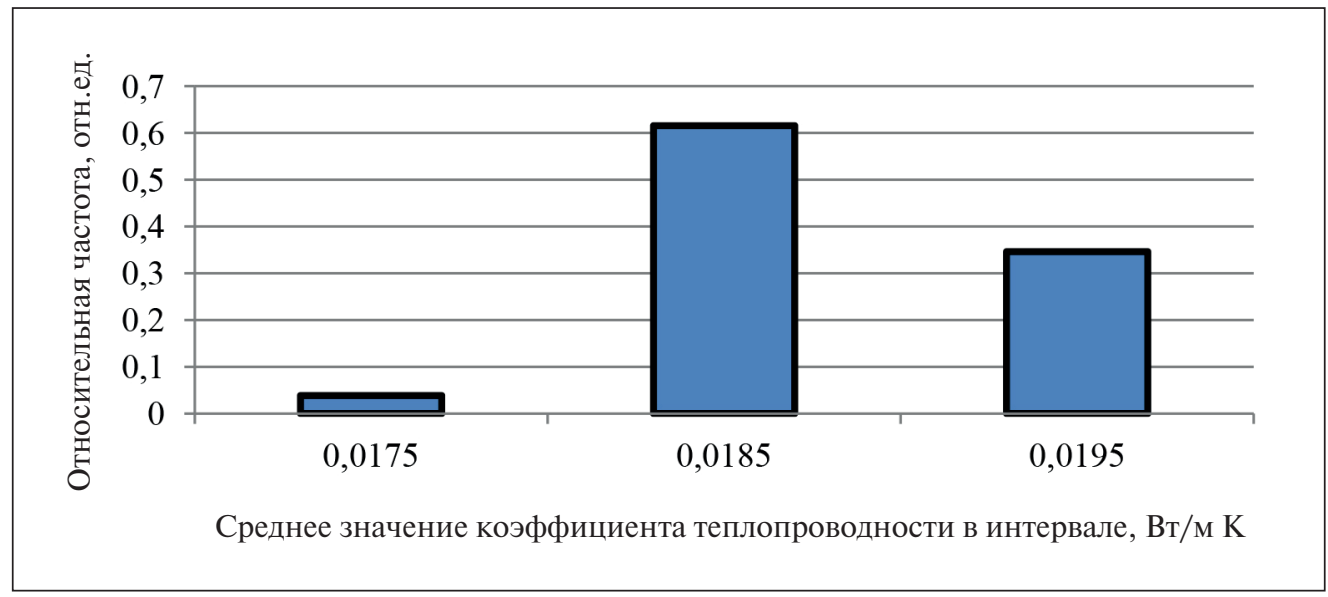

Рис. 3. Гистограмма относительных частот

При этом, на образце толщиной 20 мм прослеживается достаточно четкая возрастающая зависимость теплопроводности от температуры, соответствующая данным производителя теплоизоляционного материала.

Результаты, полученные на образце толщиной 30 мм, имеют достаточное количество шумовых помех, помешавших более точному определению искомой величины.

Построение модели для данных с большим разбросом дает приближенное решение с низкой ве- личиной достоверности. Для повышения точности определения зависимости был использован метод порядковых статик или порядковое приближение монотонной зависимости [23]. При этом, из полученных экспериментальных данных восстанавливают монотонную зависимость, в соответствии с заранее известным законом распределения. В частности, для теплопроводности это монотонно возрастающая функция. Результат применения метода порядковых статик для экспериментальных данных, полученных на образце толщиной 30 мм, 


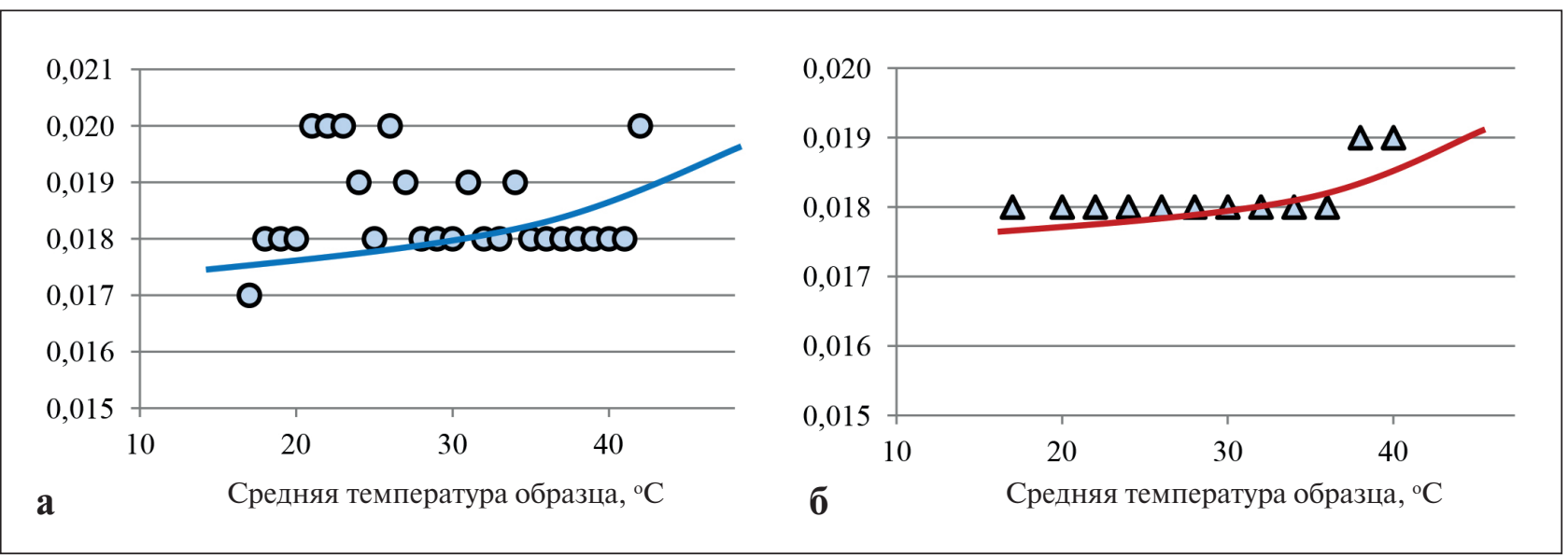

Рис. 4. Зависимость коэффициента теплопроводности материала от средней температуры образца аэрогеля: а - толщина образца 30 мм; б - толщина образца 20 мм

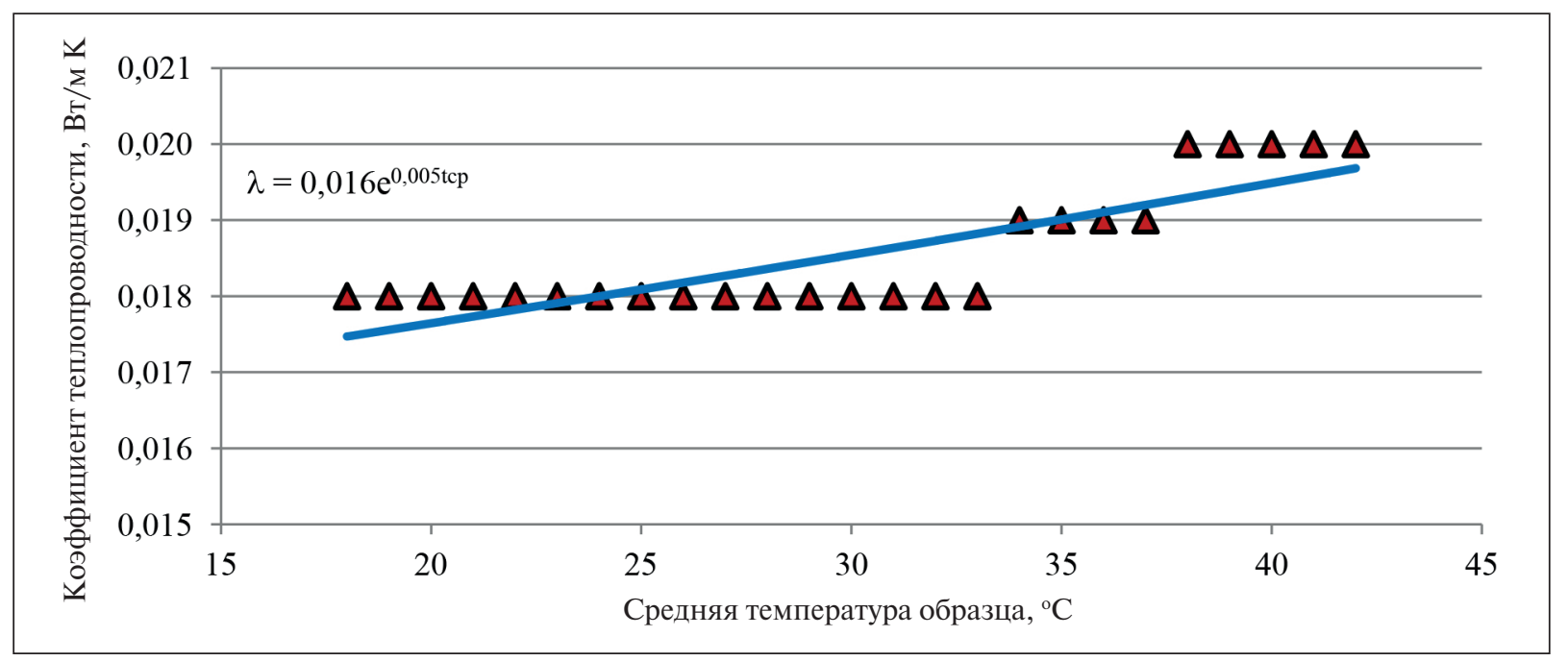

Рис. 5. Восстановленная методом порядковых статик зависимость коэффициента теплопроводности аэрогеля от средней температуры

представлен на рис. 5. Данные результаты имеют более высокую величину достоверности, по сравнению с начальными данными, что подтверждает эффективность данного метода для восстановления монотонных зависимостей.

\section{ЗАКЛЮЧЕНИЕ}

1. Экспериментально установлено среднее значение коэффициента теплопроводности теплоизоляционного материала на основе кремнийоксидного аэрогеля - Insuflex - на уровне 0,0185 Вт/мК, что существенно ниже аналогичных показателей для прочих теплоизоляционных материалов в температурном режиме работы систем теплоснабжения.

2. Получено уравнение однопараметрической регрессии зависимости коэффициента теплопроводности аэрогельной тепловой изоляции от средней температуры материала.

3. Низкое значение коэффициента теплопроводности материала свидетельствует о высокой его энергоэффективности. Применение тепловой изоляции на основе аэрогеля позволит снизить тепловые потери не менее, чем на 47\% по сравнению с применяемыми в системах теплоснабжения теплоизоляционными материалами. 


\section{REFERENCES}

1. Baikov I.R., Smorodova O.V., Kitaev S.V. Investigation of properties of liquid ceramic thermal insulation materials. Nanotehnologii v stroitel'stve $=$ Nanotechnologies in Construction. 2018, Vol. 10, no. 5, pp. 106-121. DOI: dx.doi. org/10.15828/20758545-2018-10-5-106-121. (In Russian).

2. Kistler S.S. Coherent expanded aerogels and jellies. Nature. 1931. Vol. 127 (3211). P. 741.

3. Pimenov V.G., Sheveleva Ye.Ye., Sakharov A.M. Ustanovka dlya sverkhkriticheskoy sushki: izgotovleniye, opyt raboty i polucheniye nizkoplotnykh polimernykh aerogeley [Installation for supercritical drying: manufacturing, work experience and obtaining low-density polymer airgels].Sverkhkriticheskiye flyuidy: Teoriya i praktika [Supercritical fluids: Theory and practice]. 2011. Vol. 6. No. 4. Pp. 77-87. (In Russian).

4. Pierre A.C., Pajonk G.M. Chemistry of Aerogels and Their Applications. Chem. Rev. 2002. V. 102. pp. $4243-4265$.

5. Rubtsov I.V., Denisov I.A., Varlamov B.S. Aerogel' - material budushchego [Airgel - the material of the future].V sbornike: V Mezhdunarodnaya nauchno-prakticheskaya konferentsiya molodykh uchenykh, posvyashchennaya 54-y godovshchine poleta YU.A. Gagarina v kosmos sbornik nauchnykh statey. Filial VUNTS VVS «VVA» imeni professora N.Ye. Zhukovskogo i YU.A. Gagarina [In the collection: V International scientific and practical conference of young scientists dedicated to the 54th anniversary of the flight of Yu.A. Gagarin in space collection of scientific articles. Branch of VUNC Air Force "VVA" named after Professor N.E. Zhukovsky and Yu.A. Gagarin] (Krasnodar). 2015. C. 63-67. (In Russian).

6. Hwang S.E., Jang H.H., Hyun H.H., Ahn Y.S. Effective preparation of crack-free silica aerogels via ambient drying. J. SolGel Sci. Techn. 2007. No. 41. Pp.139-146.

7. Yokogawa H. Thermal Conductivity of Silica Aerogels. Handbook of Sol_Gel Science \& Technologyll, vol. 2(13). 2005. Kluwer Academic Publishers, New York, USA.

8. Dowson M., Harrison D., Craig S., Gill Z. Improving the Thermal Performance of Single Glazed Windows using Translucent Granular Aerogel. International Journal of Sustainable Engineering. 2011. No. 4(3). Pp. 266-280.

9. Men'shutina N.V., Katalevich A.M., Smirnova I. Polucheniye aerogeley na osnove dioksida kremniya metodom sverkhkriticheskoy sushki [Obtaining airgels based on silicon dioxide by the method of supercritical drying]. Sverkhkriticheskiye flyuidy: Teoriya i praktika [Supercritical fluids: Theory and practice.] 2013. Vol. 8. No 3. Pp. 49-55. (In Russian).

10. Pustovgar A.P., Vedenin A.D. Teploizolyatsionnyye nanokompozity na osnove aerogelya kremnezema [Heat-insulating nanocomposites based on silica airge]. Nauchno-tekhnicheskiy vestnik Povolzh'ya [Scientific and Technical Bulletin of the Volga Region]. 2013. No 1. Pp. 252-254. (In Russian). Available at: https://elibrary.ru/download/elibrary_18800022_16720559.pdf. (accessed: 10.08.2019).

11. Buznik V.M., Kablov Ye.N., Koshurina A.A. Materialy dlya slozhnykh tekhnicheskikh ustroystv arkticheskogo primeneniya [Materials for complex technical devices of Arctic use]. Nauchno-tekhnicheskiye problemy osvoyeniya Arktiki [Scientific and technical problems of Arctic development] RAN. M.: Nauka, [RAS. M.: Nauka,] 2015. Pp. 275-285. (In Russian).

12. Dolbin A.V., Khlystyuk M.V., Yesel'son V.B., Gavrilko V.G., Vinnikov N.A., Basnukayeva R.M. Sorbtsiya vodoroda kremniyoksidnym aerogelem pri nizkikh temperaturakh [Hydrogen sorption by silicon oxide airgel at low temperatures]. Fizika nizkikh temperature [Low Temperature Physics] 2018. Vol. 44. No 2. Pp. 191-196. (In Russian). Available at: https://elibrary.ru/download/ elibrary_32266236_44926583.pdf. (accessed: 10.08.2019).

13. Men'shutina N.V., Katalevich A.M., Lebedev A.Ye. Nanostrukturirovannyye materialy na osnove dioksida kremniya: aerogel', kserogel', kriogel' [Nanostructured materials based on silicon dioxide: airgel, xerogel, cryogel]. Yestestvennyye i tekhnicheskiye nauki [Natural and technical sciences.] 2013. No. 2 (64). Pp. 374-376. (In Russian).

14. Ismail A.A., Ibrahim I.A. Impact of supercritical drying and heat treatment on physical properties of titania/silica aerogel monolithic and its applications. J. Applied Catalysis A: General. 2008. Vol. 346 (1-2). Pp. 200-205.

15. Kwon Y.G., Choi S.Y., Kang E.S., Baek S.S. Ambient-dried silica aerogel doped with $\mathrm{TiO}_{2}$ powder for thermal insulation. J. Mater. Sci. 2000. No. 35. Pp. 6075-6079.

16. Ivanov N.N., Ivanov A.N. Teploizolyatsionnyy aerogel' i p'yezoaktivnaya plenka PVDF - sovremennyye, perspektivnyye materialy dlya kosmicheskoy tekhniki i kosmicheskogo priborostroyeniya [Heat-insulating airgel and piezoactive PVDF film - modern, promising materials for space technology and space instrument engineering].Vestnik NPO im. S.A. Lavochkina [Issue NPO after S.A. Lavochkin.] 2011. No 2 (8). Pp. 46-52. (In Russian). Available at: https://elibrary.ru/download/elibrary_16386904_43616464. pdf. (accessed: 10.08.2019).

17. Kuznetsova Ye.V., Turumtayev G.R., Khristolyubova D.V. Ekonomicheskoye obosnovaniye primeneniya sovremennykh teploizolyatsionnykh materialov v stroitel'noy otrasli [The economic rationale for the use of modern thermal insulation materials in the construction industry]. Yevraziyskiy yuridicheskiy zhurnal [Eurasian Law Journal.] 2018. No. 11 (126). Pp. 393-394. (In Russian).

18. Askhadullin R.Sh., Osipov A.A., Gulevskiy V.A., Ul'yanov V.V., Ivanov I.I., Kharchuk S.Ye. Issledovaniye mekhanizmov sinteza anizotropnykh nanostruktur v zhidkikh metallakh. Svoystva i perspektivnyye oblasti ikh primeneniya [Study of the synthesis mechanisms of anisotropic nanostructures in liquid metals. Properties and promising areas of their application]//V sbornike: Trudy regional'nogo konkursa proyektov fundamental'nykh nauchnykh issledovaniy [In the collection: Proceedings of the regional competition of fundamental scientific research projects] Kaluga, 2016. Pp. 84-97. (In Russian). Available at: https://elibrary.ru/ download/elibrary_28430107_60072610.pdf. (accessed: 10.08.2019).

19. Razd'yakonova G.I., Kokhanovskaya O.A., Likholobov V.A. Sintez poroshkov aerogel'nogo tipa na osnove tekhnicheskogo ugleroda [Synthesis of airgel-type powders based on carbon black].Perspektivnyye materialy [Promising material]. 2014. No. 8. Pp. 68-74. (In Russian). Available at: https://elibrary.ru/download/elibrary_21844829_77073953.pdf. (accessed: 10.08.2019). 
20. Martynov P.N., Askhadullin R.SH., Yudintsev P.A. Aerogel' ALOOH: polucheniye, svoystva, primeneniye [Airgel ALOOH: production, properties, application]. Nanotekhnika [Nanotechnology]. 2006. No. 1 (5). Pp. 35-41. (In Russian).

21. Vedenin A.D., Vityaz' P.A., Galinovskiy A.L., Ivanova I.S., Mazalov YU.A., Pustovgar A.P., Sudnik L.V. Eksperimental'noye issledovaniye teploizolyatsionnykh aerogel'nykh kompozitov gidrotermal'nogo reaktora [An experimental study of heat-insulating airgel composites of a hydrothermal reactor]. Tekhnologiya metallov [Metal Technology]. 2016. No. 4. Pp. 43-47. (In Russian).

22. Kiyamov I.K., Vachitova R.I., Saracheva D.A., Mazankina D.V., Sitdikova I. P. The use of nanomaterials in pipe insulation. Nanotehnologii v stroitel'stve $=$ Nanotechnologies in Construction. 2019, Vol. 11, no. 2, pp. 194-202. DOI: 10.15828/2075-85452019-11-2-194-202.

23. Saati T. Prinyatiye resheniy pri zavisimostyakh v obratnykh svyazyakh: Analiticheskiye seti [Decision making with dependencies in feedbacks: Analytical networks]/ per. s angl.; nauch. red. A.V. Andreychenkov, O.N. Andreychenkova [trans. from English; scientific ed. A.V. Andreichenkov, O.N. Andreichenkova]. Moskva. Izdatel'stvo LKI [Moscow: Publishing house LCI], 2008. 360 p. (In Russian).

\section{СПИСОК ЛИТЕРАТУРЫ}

1. Байков И.Р., Смородова О.В., Китаев С.В. Исследование свойств жидких керамических теплоизоляционных материалов/ / Нанотехнологии в строительстве. - 2018. - Т.10, № 5. - C. 106-121. - URL: https://elibrary.ru/download/ elibrary_36402454_87767770.pdf. (дата обращения: 10.08.2019).

2. Kistler S.S. Coherent expanded aerogels and jellies // Nature. 1931. Vol. 127 (3211). P. 741.

3. Пименов В.Г., Шевелева Е.Е., Сахаров А.М. Установка для сверхкритической сушки: изготовление, опыт работы и получение низкоплотных полимерных аэрогелей // Сверхкритические флюиды: Теория и практика. - 2011. - Т. 6, № 4. - C. 77-87.

4. Pierre A. C., Pajonk G. M. Chemistry of Aerogels and Their Applications // Chem. Rev. 2002. V. 102. pp. 4243-4265.

5. Рубцов И.В., Денисов И.А., Варламов Б.С. Аэрогель - материал будущего // V Международная научно-практическая конференция молодых ученых, посвященная 54-й годовщине полета Ю.А. Гагарина в космос: сборник научных статей. Филиал ВУНЦ ВВС «ВВА» имени профессора Н.Е. Жуковского и Ю.А. Гагарина (г. Краснодар). - 2015. - С. $63-67$.

6. Hwang S.E., Jang H.H., Hyun H.H., Ahn Y.S. Effective preparation of crack-free silica aerogels via ambient drying. J. SolGel Sci. Techn. 2007. No. 41. Pp.139-146.

7. Yokogawa H. Thermal Conductivity of Silica Aerogels. - Handbook of Sol_Gel Science \& Technologyll, vol. 2(13). 2005. Kluwer Academic Publishers, New York, USA.

8. Dowson M., Harrison D., Craig S., Gill Z. Improving the Thermal Performance of Single Glazed Windows using Translucent Granular Aerogel. International Journal of Sustainable Engineering. 2011. No. 4(3). Pp. 266-280.

9. Меньшутина Н.В., Каталевич А.М., Смирнова И. Получение аэрогелей на основе диоксида кремния методом сверхкритической сушки // Сверхкритические флюиды: Теория и практика. - 2013. - Т. 8, № 3. - С. 49-55.

10. Пустовгар А.П., Веденин А.Д. Теплоизоляционные нанокомпозиты на основе аэрогеля кремнезема // Научно-технический вестник Поволжья. - 2013. - № 1. - C. 252-254. - URL: https://elibrary.ru/download/elibrary_18800022_16720559. pdf. (дата обращения: 10.08.2019).

11. Бузник В. М., Каблов Е. Н., Кошурина А. А. Материалы для сложных технических устройств арктического применения // Научно-технические проблемы освоения Арктики. - РАН. - М.: Наука, 2015. - С. $275-285$.

12. Долбин А.В., Хлыстюк М.В., Есельсон В.Б., Гаврилко В.Г., Винников Н.А., Баснукаева Р.М. Сорбция водорода кремнийоксидным аэрогелем при низких температурах // Физика низких температур. - 2018. - Т. 44, № 2. - С. 191-196. URL: https://elibrary.ru/download/elibrary_32266236_44926583.pdf. (дата обращения: 10.08.2019).

13. Меньшутина Н.В., Каталевич А.М., Лебедев А.Е. Наноструктурированные материалы на основе диоксида кремния: аэрогель, ксерогель, криогель // Естественные и технические науки. - 2013. - № 2 (64). - С. 374-376.

14. Ismail A.A., Ibrahim I.A. Impact of supercritical drying and heat treatment on physical properties of titania/silica aerogel monolithic and its applications. J. Applied Catalysis A:General. 2008. Vol. 346(1-2). Pp. 200-205.

15. Kwon Y.G., Choi S.Y., Kang E.S., Baek S.S. Ambient-dried silica aerogel doped with TiO2 powder for thermal insulation. J. Mater. Sci. 2000. No. 35. Pp. 6075-6079.

16. Иванов Н.Н., Иванов А.Н. Теплоизоляционный аэрогель и пьезоактивная пленка PVDF - современные, перспективные материалы для космической техники и космического приборостроения // Вестник НПО им. С.А. Лавочкина. - 2011. - № 2 (8). - C. 46-52. - URL: https://elibrary.ru/download/elibrary_16386904_43616464.pdf. (дата обращения: 10.08.2019).

17. Кузнецова Е.В., Турумтаев Г.Р., Христолюбова Д.В. Экономическое обоснование применения современных теплоизоляционных материалов в строительной отрасли // Евразийский юридический журнал. - 2018. - № 11 (126). C. $393-394$.

18. Асхадуллин Р.Ш., Осипов А.А., Гулевский В.А., Ульянов В.В., Иванов И.И., Харчук С.Е. Исследование механизмов синтеза анизотропных наноструктур в жидких металлах. Свойства и перспективные области их применения // Труды регионального конкурса проектов фундаментальных научных исследований. - Калуга, 2016. - C. 84-97. - URL: https://elibrary.ru/download/elibrary_28430107_60072610.pdf. (дата обращения: 10.08.2019). 
POWER ENGINEERING NANOTECHNOLOGIES • НАНОTEХНОЛОГИИ В ЭНЕРГЕTИКE

19. Раздьяконова Г.И., Кохановская О.А., Лихолобов В.А. Синтез порошков аэрогельного типа на основе технического углерода // Перспективные материалы. - 2014. - № 8. - C. 68-74. - URL: https://elibrary.ru/download/ elibrary_21844829_77073953.pdf. (дата обращения: 10.08.2019).

20. Мартынов П.Н., Асхадуллин Р.Ш., Юдинцев П.А. Аэрогель ALOOH: получение, свойства, применение // Нанотехника. - 2006. - № 1 (5). - С. 35-41.

21. Веденин А.Д., Витязь П.А., Галиновский А.Л., Иванова И.С., Мазалов Ю.А., Пустовгар А.П., Судник Л.В. Экспериментальное исследование теплоизоляционных аэрогельных композитов гидротермального реактора // Технология металлов. - 2016. - № 4. - С. 43-47.

22. Киямов И.К., Вахитова Р.И., Сарачева Д.А., Мазанкина Д.В., Ситдикова И.П. Применение наноматериалов в теплоизоляции трубопроводов // Нанотехнологии в строительстве. - 2019. - T. 11, № 2. - C. 194-202. - URL: https:// elibrary.ru/download/elibrary_37529008_95204141.pdf. (дата обращения: 10.08.2019).

23. Саати Т. Принятие решений при зависимостях в обратных связях: Аналитические сети // А.В. Андрейченков, О.Н. Андрейченкова. - М.: Издательство ЛКИ, 2008. - 360 с.

\section{INFORMATION ABOUT THE AUTHORS}

Igor R. Baikov, Doctor of Engineering, Professor, Full member of Academy of Mining Engineering, Ufa State Petroleum Technological University; Russia, Bashkortostan Republic, Ufa, pte.ugntu@rusoil.net

Olga V. Smorodova, PhD in Engineering, Associate Professor, Ufa State Petroleum Technological University; Russia, Bashkortostan Republic, Ufa, olga_smorodova@mail.ru

Andrey Yu. Trofimov, PhD in Engineering, Associate Professor, Ufa State Petroleum Technological University; Russia, Bashkortostan Republic, Ufa, trofimov_pte@mail.ru

Elena V. Kuznetcova, PhD in Engineering, Associate Professor, Ufa State Petroleum Technological University; Russia, Bashkortostan Republic, Ufa, nsp-rb@mail.ru

\section{ИНФОРМАЦИЯ ОБ АВТОРАХ}

Байков Игорь Равильевич, д-р техн. наук, проф., действительный член Академии горных наук, ФГБОУ ВО «Уфимский государственный нефтяной технический университет»; Россия, г. Уфа, Республика Башкортостан, pte.ugntu@rusoil.net

Смородова Ольга Викторовна, канд. техн. наук, доцент, ФГБОУ ВО «Уфимский государственный нефтяной технический университет»; Россия, г. Уфа, Республика Башкортостан, olga_smorodova@mail.ru

Трофимов Андрей Юрьевич, канд. техн. наук, доцент, ФГБОУ ВО «Уфимский государственный нефтяной технический университет»; Россия, г. Уфа, Республика Башкортостан, trofimov_pte@mail.ru

Кузнецова Елена Викторовна, канд. техн. наук, доцент, ФГБОУ ВО «Уфимский государственный нефтяной технический университет»; Россия, г. Уфа, Республика Башкортостан, nsp-rb@mail.ru 